\title{
SUBTIDAL BENTHIC MARINE ALGAE OF THE MARINE STATE PARK OF LAJE DE SANTOS (SÃO PAULO, BRAZIL)*
}

\author{
Gilberto M. Amado Filho ${ }^{I}$; Paulo A. Horta ${ }^{2}$; Poliana S. Brasileiro ${ }^{I}$;
} Maria B. Barros-Barreto ${ }^{3} \&$ Mutue T. Fujii $^{4}$

${ }^{1}$ Programa Zona Costeira, Instituto de Pesquisas Jardim Botânico / MMA

(Rua Pacheco Leão 915, 22460-030 Rio de Janeiro, RJ, Brasil)

corresponding author: gfilho@jbrj.gov.br

${ }^{2}$ Universidade Federal da Paraíba, Departamento de Sistemática e Ecologia (Centro de Ciências Exatas e da Natureza - Campus I, 58059-900 João Pessoa, PB, Brasil)

${ }^{3}$ Universidade Federal Rural do Rio de Janeiro, Departamento de Botânica, Instituto de Biologia (Antiga Rodovia Rio-São Paulo km 47, 23890-000 Seropédica, RJ, Brasil)

${ }^{4}$ Secretaria de Estado do Meio Ambiente, Seção de Ficologia, Instituto de Botânica

(Av. Miguel Estéfano, 3687, Água Funda, 04301-902 São Paulo, SP, Brasil)

\begin{abstract}
A B S T R A C T
Laje de Santos Marine State Park has been pointed out as a site of high marine diversity. In spite of its importance to conservation of marine biota no results of investigations about its marine biodiversity have been published. The aim of this work was to characterize the subtidal seaweed flora of this Marine Park. Samplings were performed by scuba diving: a qualitative one that included the subtidal zone down to $26 \mathrm{~m}$ depth and other quantitative at two pre-determined depths, 10 and $20 \mathrm{~m}$. Among the 129 taxa identified, 5 species were identified for the first time for the São Paulo State, 3 for the Brazilian coast and 1 for the South Atlantic Ocean. The most abundant algae were Sargassum vulgare and turf composed by geniculate coralline and filamentous groups. The frequency of occurrence of taxa revealed that most of species are restricted to frequencies less than $20 \%$ in all samples. The analyses of the subtidal marine benthic algal flora indicate the Marine State Park of Laje de Santos as a site of elevated species richness and that its floristic composition is related to a benthic community structure dominated by turf-forming groups and population of $S$. vulgare.
\end{abstract}

\section{RESUMO}

O Parque Estadual Marinho da Laje de Santos tem sido apontado como local de elevada diversidade marinha. Apesar de sua importância para a conservação da biota marinha não existem resultados efetivamente publicados. O objetivo deste trabalho é o de caracterizar a flora marinha bentônica desse Parque Marinho. Amostragens foram realizadas por mergulho autônomo: uma qualitativa que incluiu a zona do sublitoral até a profundidade de $26 \mathrm{~m}$ e outra quantitativa em duas profundidades pré-determinadas, 10 e $20 \mathrm{~m}$.. Dentre os 129 táxons encontrados, foram identificadas pela primeira vez, 5 espécies para o Estado de São Paulo, 3 espécies para o litoral brasileiro e 1 espécie para o Atlântico sul. As algas mais abundantes foram Sargasum vulgare e tufos compostos de coralináceas geniculadas e algas filamentosas. A freqüência de ocorrência dos táxons revelou que a maioria deles ocorreu em menos de $20 \%$ das amostras. A análise da flora marinha bentônica demonstra que o Parque Estadual Marinho da Laje de Santos é um local de elevada riqueza e que sua composição florística esta relacionada a uma estrutura de comunidade bentônica dominada por populações de $S$. vulgare e grupos formadores de tufos.

Descriptors: Algal turfs, New records, Species richness, Sargassum vulgare, Seaweeds, Subtidal. Descritores: Macroalgas, Novas ocorrências, Sargassum vulgare, Riqueza de espécies, Sublitoral, Tufos de algas.

\section{INTRODUCTION}

The loss of biodiversity is the only truly irreversible global environmental change the Earth faces today (Dirzo \& Raven, 2003). In spite of its

(*) Paper presented at the $1^{\text {st }}$ Brazilian Congress of Marine Biology, on 15-19 May. Rio de Janeiro, Brazil. importance, the conservationist approaches applied in marine ecosystems are still poorly supported by consistent biological data that determine the necessity of actions that focused on biological characterization of ecosystems with a high biodiversity potential.

The Marine State Park of Laje de Santos $\left(24^{\circ} 19^{\prime} \mathrm{S}, 46^{\circ} 11^{\prime} \mathrm{W}\right)$ is the first of this category in São Paulo State. It was founded in 1993 with the aim to 
guarantee complete protection of the flora and fauna and scenic beauty of this ecosystem, one of the famous recreational diving points in southeastern Brazil (Neves, 1997). Laje de Santos has been pointed out as a locality of high marine diversity and in spite of its importance to conservation of the marine biota for the southeastern Brazilian coastal zone, no data on its marine fauna and flora have been published.

The Park includes terrestrial (Laje de Santos and Rochedos Calhaus) and underwater areas. The Laje de Santos is a granitic rocky formation and its greatest depth is $30 \mathrm{~m}$. It represents a site of great interest for conservation of the biodiversity of the São Paulo State coastal zone. The distance from the mainland (22.4 n.m.) and the absence of other nearest rocky formations (the Alcatrazes Archipelago and Queimada Grande Island are 50 miles away) allied to fishing restriction make Laje de Santos a special site for marine life and consequently scuba diving.

Shoals of fish of commercial importance like Atlantic bonito, yellow tail, sardine and other fish species are frequently observed in the Park area where they find sheltered places, abundant food and sites for reproduction, indicating the significance of this conservation unit for reposition of marine resources stocks and for the maintenance of regional fishing potential. Rocky-shore fishes such as French angel fish, groupers and parrotfish find in the Laje de Santos area ideal conditions for their survival and reproduction. The maintenance of abundance of fish, mollusks and crustaceans depends on an abundant primary production. In this way, the marine benthic algae play a fundamental role in supporting the structure of the food web base in rocky shores and reef ecosystems (Chapin et al., 1997).

The benthic marine algae are one of the well known group of marine organisms from Brazil as a result of continuous efforts started in the 1950s by the Brazilian pioneer phycologist Aylthon B. Joly. However, the knowledge of the Brazilian marine benthic flora is mainly concerned with samples from the intertidal zone and from upper levels of the subtidal zone. Benthic algae from depths greater than 3 meters are poorly known until recently (Horta, 2000).

Sampling methods using Scuba diving techniques allow the realization of detailed samplings in areas permanently submersed. Nevertheless its use for sampling benthic communities in Brazil is very recent. Studies that stand out are those by Eston et al. (1986), who evaluated the vertical distribution of benthic communities down to $30 \mathrm{~m}$ depth in Fernando de Noronha Archipelago, and Horta (2000), who characterized the marine algae of coastal islands from south and southeastern Brazilian regions down to 32 meters depth.
In a broad sense, the velocity of natural system degradations is faster than the velocity of conservation initiatives. In order to implement management and conservation initiatives in marine ecosystems, it is necessary to determine the structure and dynamic patterns of communities and populations. In this way, the aim of this work is to characterize the subtidal seaweeds composition of the Laje de Santos Marine State Park. This work is part of the Project "Phycological flora of the São Paulo State" included in the BIOTA-FAPESP Program.

\section{Material and Methods}

Two kinds of sampling approach were done by scuba diving, one qualitative that included the entire subtidal zone down to a depth of $26 \mathrm{~m}$, and other quantitative in two pre-determined depths. Qualitative sampling was performed in November, 1998 and quantitative samplings in January and October, 2001. Results of species collected in 1998 are part of Paulo A. Horta PhD presented in 2000 at the University of São Paulo, Brazil. In qualitative sampling all specific habitats of the rocky shore, like crevices, limit of rocks and sand, were explored to obtain the possible maximum number of species for the area. For quantitatative purposes two transect lines of $20 \mathrm{~m}$ length were positioned horizontally at 10 and $20 \mathrm{~m}$ depth, respectively, along the north-northeastern face of the Laje de Santos, where the rocky shore substrates were uniform. The substrate presented an inclination angle of $30^{\circ}$ and $45^{\circ}$, respectively, at 10 and $20 \mathrm{~m}$ depth. At each transect line, eight quadrats of $0.625 \mathrm{~m}^{2}$ were randomly positioned, and all the content of each quadrat was scraped with a dive knife and transferred to collection bags. Later, all samples were fixed on formalin $4 \%$ in seawater.

In the laboratory, samples were separated for taxonomic identification and quantification. The nomenclature followed Wynne (2005).

The evaluation of algae abundance in quadrats was determined by dry biomass. After the identification, the population of each species found in each quadrat was separated under a stereomicroscope. In the case of cushion-like turfs composed mainly by entangled geniculate coralline algae and many filamentous species, the separation of individuals of specific population became impossible. In this case, we included the species in two main morphological categories, the geniculate corallines group and the filamentous group. After separation, populations and groups of each quadrat were dried at $60^{\circ} \mathrm{C}$ for 48 hours and then weighed on an analytical balance. The frequency of occurrence of each species in the two analyzed depths was determined. Multi-dimensional scale in two dimension was performed based on the similarity index of Bray-Curtis to compare 
quantitative data among depths and season of the year, and one way ANOVA was applied to evaluate differences in total biomass among depths and season. The statistical analyses were performed with the software PRIMER (version 5.0).

\section{Results}

A total of 129 taxa of marine benthic algae were identified in the Laje de Santos, 9 belonging to Chlorophyta, 12 to Ochrophyta and 108 to Rhodophyta (Table 1). Among Chlorophyta, the order Cladophorales, with 6 species, was the most representative; among Ochrophyta, the order
Dictyotales was represented by 7 species and among Rhodophyta, the order Ceramiales included 56 taxa. Twelve new records were found: 5 for the São Paulo State (Craspedocarpus jolyi, Griffithsia shousboei var. anastomosans, Osmundea lata, Sporochnus pedunculatus, Valonia utricularis), 3 for the Brazilian coast (Botryocladia wynnei, Myriogramme prostrata, Rhodymenia delicatula), 1 for South Atlantic Ocean (Cladosiphon occidentalis). Among the 129 taxa identified, 75 were found in qualitative sampling, 92 were found in quantitative sampling, 36 were common to both analyzes, 37 were exclusive to qualitative and 56 were exclusive to quantitative sampling.

Table 1. List of Laje de Santos taxa collected in qualitative sampling (1998, July) and quantitative samplings (2001, January, 20 and $10 \mathrm{~m}$ depths; October, 20 and $10 \mathrm{~m}$ depths).

\begin{tabular}{|c|c|c|c|c|c|}
\hline \multirow[t]{3}{*}{ Taxa } & \multicolumn{5}{|c|}{ Sampling } \\
\hline & \multirow{2}{*}{$\begin{array}{c}\text { Quali } \\
\text { Jul/98 }\end{array}$} & \multicolumn{4}{|c|}{ Quantitative } \\
\hline & & Jan/20 m & Jan/10 m & Oct $/ 20 \mathrm{~m}$ & Oct $/ 10 \mathrm{~m}$ \\
\hline \multicolumn{6}{|l|}{ CHLOROPHYTA } \\
\hline Cladophorales & + & - & - & - & - \\
\hline Chaetomorpha aerea (Dillwyn) Kütz. & + & - & - & - & - \\
\hline Cladophora capensis (C. Agardh) De Toni & + & - & - & - & - \\
\hline Cladophora vagabunda (L.) C. Hoek & + & + & - & - & - \\
\hline Cladophora sp & - & + & - & + & + \\
\hline Ernodesmis verticillata (Kütz.) Børgesen & + & - & + & - & + \\
\hline *Valonia utricularis (Roth) C. Agardh & + & - & - & - & - \\
\hline \multicolumn{6}{|l|}{ Bryopsidales } \\
\hline Bryopsis pennata J.V. Lamour. & + & + & - & - & + \\
\hline Bryopsis plumosa (Huds.) C. Agardh & + & - & - & - & - \\
\hline Codium intertextum Collins \& Herv. & + & - & - & - & + \\
\hline \multicolumn{6}{|l|}{ OCHROPHYTA } \\
\hline \multicolumn{6}{|l|}{ Ectocarpales } \\
\hline ***Cladosiphon occidentalis Kylin & - & + & + & - & - \\
\hline Feldmania irregularis (Kütz.) Hamel & - & + & - & - & - \\
\hline Hincksia mitchelliae (Harv.) P.C. Silva & + & + & - & - & - \\
\hline Pseudolithoderma sp & - & + & - & - & - \\
\hline \multicolumn{6}{|l|}{ Sporochnales } \\
\hline *Sporochnus pedunculatus (Huds.) C. Agardh & + & - & - & - & - \\
\hline \multicolumn{6}{|l|}{ Dictyotales } \\
\hline Dictyopteris delicatula J.V. Lamouroux & + & + & + & + & + \\
\hline Dictyopteris plagiogramma (Mont.) Vickers & + & + & - & - & - \\
\hline Dictyota cervicornis f. cervicornis Kütz. & + & + & + & + & + \\
\hline Dictyota menstrualis (Hoyt) Schnetter, Hörnig \& Weber-Peukert & + & - & - & - & - \\
\hline $\begin{array}{l}\text { Lobophora variegata (J.V. Lamouroux) Womersley ex E.C } \\
\text { Oliveira }\end{array}$ & + & + & + & + & + \\
\hline Padina gymnospora (Kütz.) Sond. & + & + & + & + & + \\
\hline Spatoglossum schroederi (C. Agardh) Kütz. & + & - & - & - & - \\
\hline
\end{tabular}




\section{Fucales}

Sargassum vulgare C. Agardh var. vulgare RHODOPHYTA

Stylonematales

Stylonema alsidii (Zanardini) K.M. Drew

Erythropeltidales

Erythrotrichia carnea (Dillwyn) J. Agardh

Erythrotrichia porphyroides N. L. Gardner

Sahlingia subintegra (Rosenv.) Kornmann

Acrochaetiales

Acrochaetium hallandicum (Kylin) Hamel

Acrochaetium microscopicum (Nägeli ex Kütz.) Nägeli

Acrochaetium savianum (Menegh.) Nägeli

\section{Corallinales}

Amphiroa anastomosans Weber Bosse

Amphiroa beauvoisii J.V. Lamour.

Haliptilon cubense (Mont. ex Kütz.) Garbary \& H.W. Johans.

Jania adhaerens J.V. Lamour

Jania crassa J.V. Lamour.

Jania ungulata (Yendo) Yendo

Lithophyllum frondosum ( L. Dufour) G. Furnari, Cormaci \& Alongi

Gelidiales

Gelidiella trinitatensis W. R. Taylor

Gelidium crinale (Turner) Gaillon

Gelidium parvulum Grev. in J. St.-Hil.

Gelidium sp

Pterocladiella cf. caerulescens (Kütz.) Santelices \& Hommersand

Pterocladiella capillacea (Gmelin) Santel. \& Hommers.

\section{Bonnemaisoniales}

Asparagopsis taxiformis (Delile) Trevis.

\section{Gigartinales}

*Craspedocarpus jolyi (E.C. Oliveira) C.W. Schneider

Chondracanthus acicularis (Roth) Fredericq

Chondracanthus teedei (Mertens ex Roth) Fredericq

Hypnea musciformis (Wulfen in Jacquin) J.V. Lamour.

Hypnea spinella (C. Agardh) Kütz.

Hypnea valentiae (Turner) Mont.

Hypnea volubilis Searles in Schneider \& Searles

Solieria filiformis (Kütz.) P.W. Gabrielson

Wurdemania miniata (Spreng.) Feldmann \& Hamel

Plocamiales

Plocamium brasiliense (Grev. In J. St.-Hil.) M. Howe \& W.R.

Taylor

Halymeniales

Cryptonemia delicatula A.B. Joly \& Cordeiro in Joly et al.

Halymenia rosea Howe \& W.R. Taylor 


\section{Gracilariales}

Gracilaria sp

Rhodymeniales

Botryocladia pyriformis (Børgesen) Kylin

**Botryocladia wynnei D. L. Ballant.

Champia minuscula A.B. Joly \& Ugadim

Champia parvula (C. Agardh) Harv.

Champia salicornioides Harv.

Champia taironensis Bula-Meyer

Champia vieillardii Kütz.

Gastroclonium parvum (Hollenb.) C.F. Chang \& B.M. Xia

Gelidiopsis intricata (C. Agardh) Vickers

Gelidiopsis planicaulis (W.R. Taylor) W.R. Taylor

Gelidiopsis variabilis (Grev. Ex J. Agardh) F. Schmitz

Gloiocladia iyoensis (Okamura) R.E. Norris

Gloiocladia atlantica (Searles) R.E. Norris

Leptofauchea brasiliensis A.B. Joly

Lomentaria corallicola Børgesen

**Rhodymenia delicatula Dangeard

Rhodymenia pseudopalmata (J.V. Lamour.) P.C. Silva

Rhodymenia $\mathrm{sp}$

Ceramiales

Acrosorium decumbens (J. Agardh) Kylin

Acrosorium ciliolatum (harv.) Kylin

Aglaothamnion sp.

Anotrichium tenue (C. Agardh) Nägeli

Anotrichium yagii (Okamura) Baldock

Antithamnionella breviramosa (E.Y. Dawson) Wollaston in

Womersley \& Bailey

Callithamnion corymbosum (Sm.) Lyngb.

Centroceras clavulatum (C. Agardh in Kunth) Mont. In Durieu

Maisonneuve

Ceramium brasiliense A.B. Joly

Ceramium brevizonatum var. caraibicum H.E. Petersen \& Børgesen

Ceramium clarionense Setch. \& N. L. Gardn.

Ceramium codii (H. Richards) Maz.

Ceramium comptum Børgesen

Ceramium dawsonii A.B. Joly

Ceramium deslongchampsii Chauv. ex Duby

Ceramium flaccidum (Kütz.) Ardiss.

Ceramium luetzelburgii O.C. Schmidt

Ceramium vagans P.C. Silva

Ceramium $\mathrm{sp}$

Chondria atropurpurea Harv.

Chondria cf. platyramea A.B. Joly \& Ugadim in Joly et al.

Crouania attenuata (C. Agardh) J.Agardh

Cryptopleura peltata (Montagne) M.J. Wynne 


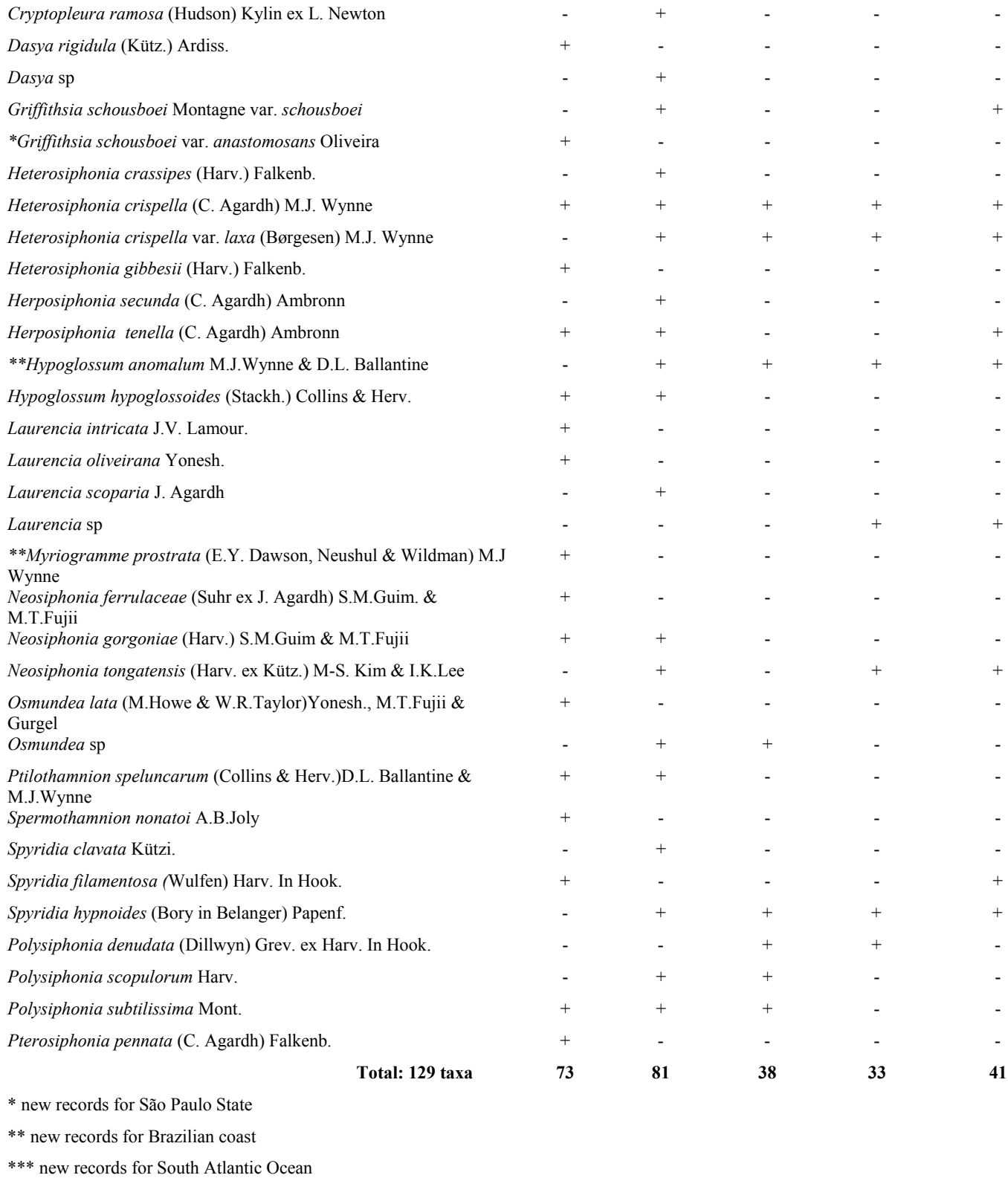

In quantitative analyzes, 41 species (45\%) were restricted to one depth on one sample date. The highest species richness (81 taxa) was observed at 20 $\mathrm{m}$ depth in January, and 36 taxa were found exclusively in this sample. The lower species richness, 33 taxa, was observed in October at the same depth. The distinction between the $20 \mathrm{~m}$ depth in January and the other depth and season was clearly demonstrated by multi-dimensional ordination (MDS) based on the Bray-Curtis similarity index (Fig. 1).

The frequency of occurrence of taxa in depths revealed that most of species are restricted to frequencies lower than $20 \%$ in all samples (Fig. 2). In January, at $20 \mathrm{~m}$, just the species Cladosiphon occidentalis, Dictyota cervicornis, Lobophora variegata, Sargassum vulgare and species of geniculate coralline group presented a frequency equal or higher than $50 \%$. In January, at $10 \mathrm{~m}$, the more frequent species were Spyridia hypnoides, Sargassum vulgare, Asparagopsis taxiformis, Ceramium flaccidum 


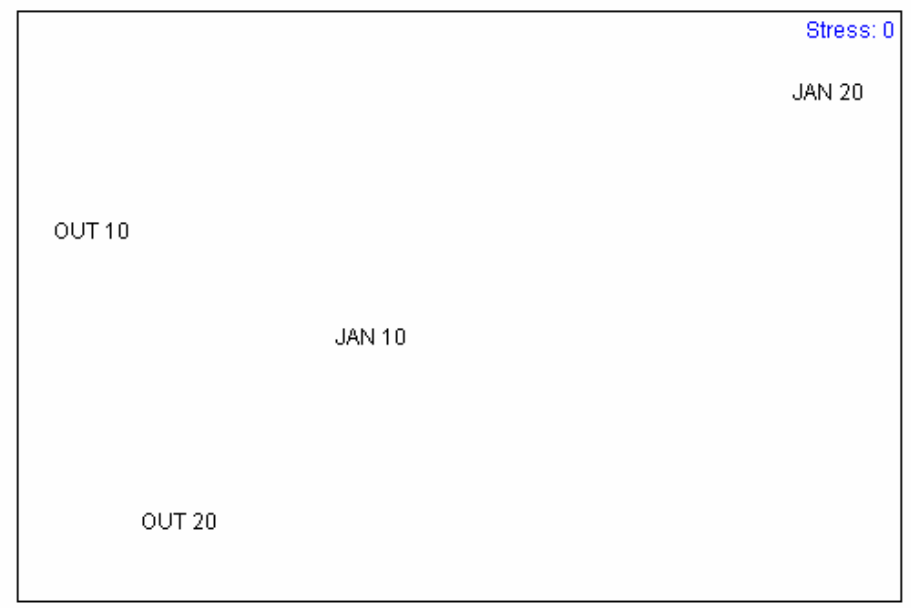

Fig. 1. Multi-dimensional ordination (MDS) based on Bray-Curtis similarity index of the two sampled depths $(20$ and $10 \mathrm{~m})$ in two collected dates (January and October 2001).
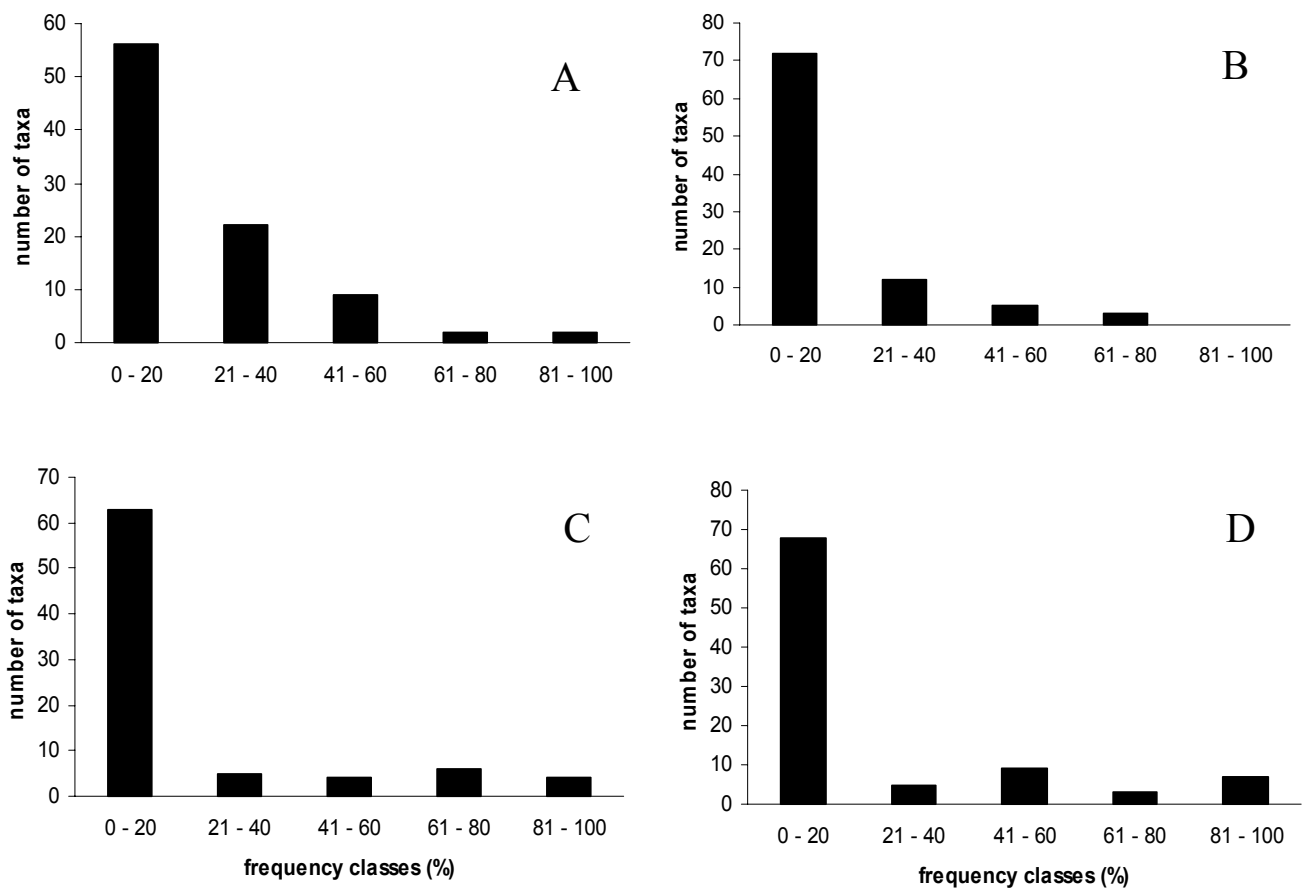

Fig. 2. Number of taxa in classes of occurrence frequency. $A=$ January $20 \mathrm{~m}, \mathrm{~B}=$ January $10 \mathrm{~m} ; \mathrm{C}=$ October 20 $\mathrm{m} ; \mathrm{D}=$ October $10 \mathrm{~m}$. 
and Chondracanthus acicularis. In samples in October, 10 species presented a frequency at least equal to $50 \%$ of the quadrats, at $20 \mathrm{~m}$ the more frequent species were: Lobophora variegata, Dictyota cervicornis, Padina gymnospora, Sargassum vulgare, Anotrichium tenue, Heterosiphonia crispella var. laxa Hypnea spinella, Plocamium brasiliensis and Wurdemania miniata Meanwhile at $10 \mathrm{~m}$ the more frequent species were Ernodesmis verticillata, Sargassum vulgare, Anotrichium tenue, Asparagopsis taxiformis, Champia salicornioides, Hypnea spinella, Heterosiphonia crispella var. laxa, Neosiphonia tongatensis, Spyridia hypnoides and species of the geniculate coralline group. Just one species, Sargassum vulgare, presented a frequency of occurrence equal or higher than $50 \%$ at both depths and seasons.

Total biomass varied from $209 \pm 82$ g.m $\mathrm{m}^{-2}$ in January $20 \mathrm{~m}$ to $105+102$ g.m $\mathrm{m}^{-2}$ in October at $10 \mathrm{~m}$ (Fig. 3). No significant differences $(\mathrm{p}<0.05)$ were detected among depths and temporal samplings. An increase of standard deviation was observed in October samples in both depths in relation to the January samples.. This increase should be attributed to higher heterogeneity of biomass data among quadrats in October; at $10 \mathrm{~m}$ the biomass varied from 40 to 287 g. $\mathrm{m}^{-2}$ and at $20 \mathrm{~m}$ from 50 to 296 g. $\mathrm{m}^{-2}$.

In Figure 4, the biomass of species and groups is presented. The species that contributed most to the biomass in Laje de Santos were Sargassum vulgare, Lobophora variegata and the groups of filamentous and geniculate coralline. Although some changes are present in the order of the species that most contributed to the biomass, no significant changes were verified among depths and seasons. The geniculate coralline group was composed mainly by the following species: Haliptilon cubense, Jania adhaerens, J. crassa, Amphiroa anastomosans and $A$. beauvoisii. The filamentous group comprised the majority of the taxa found in Laje de Santos including Chlorophya, Ochrophyta and Rhodophyta species.

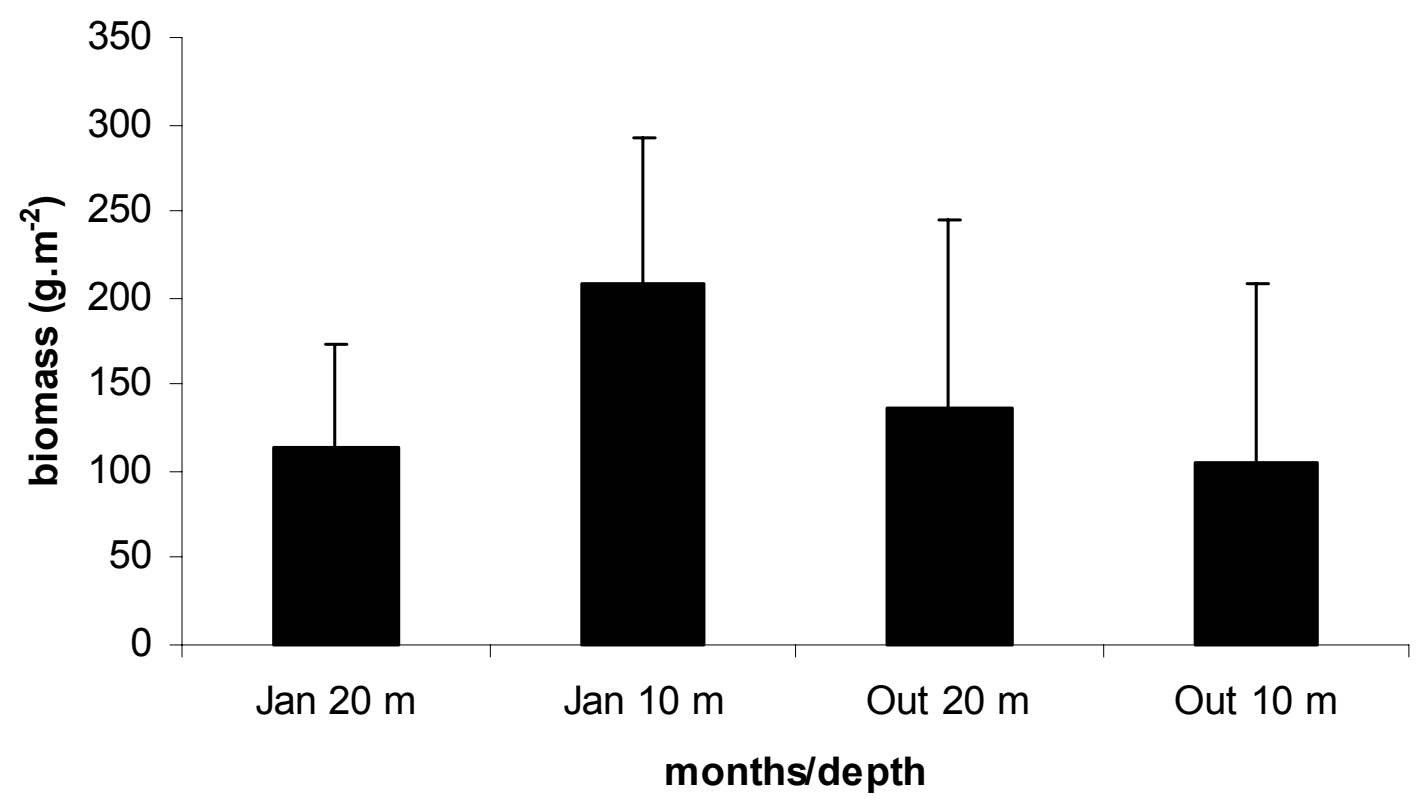

Fig. 3. Mean (and standard deviation) total dry biomass of seaweed in each depth and sampled month. 

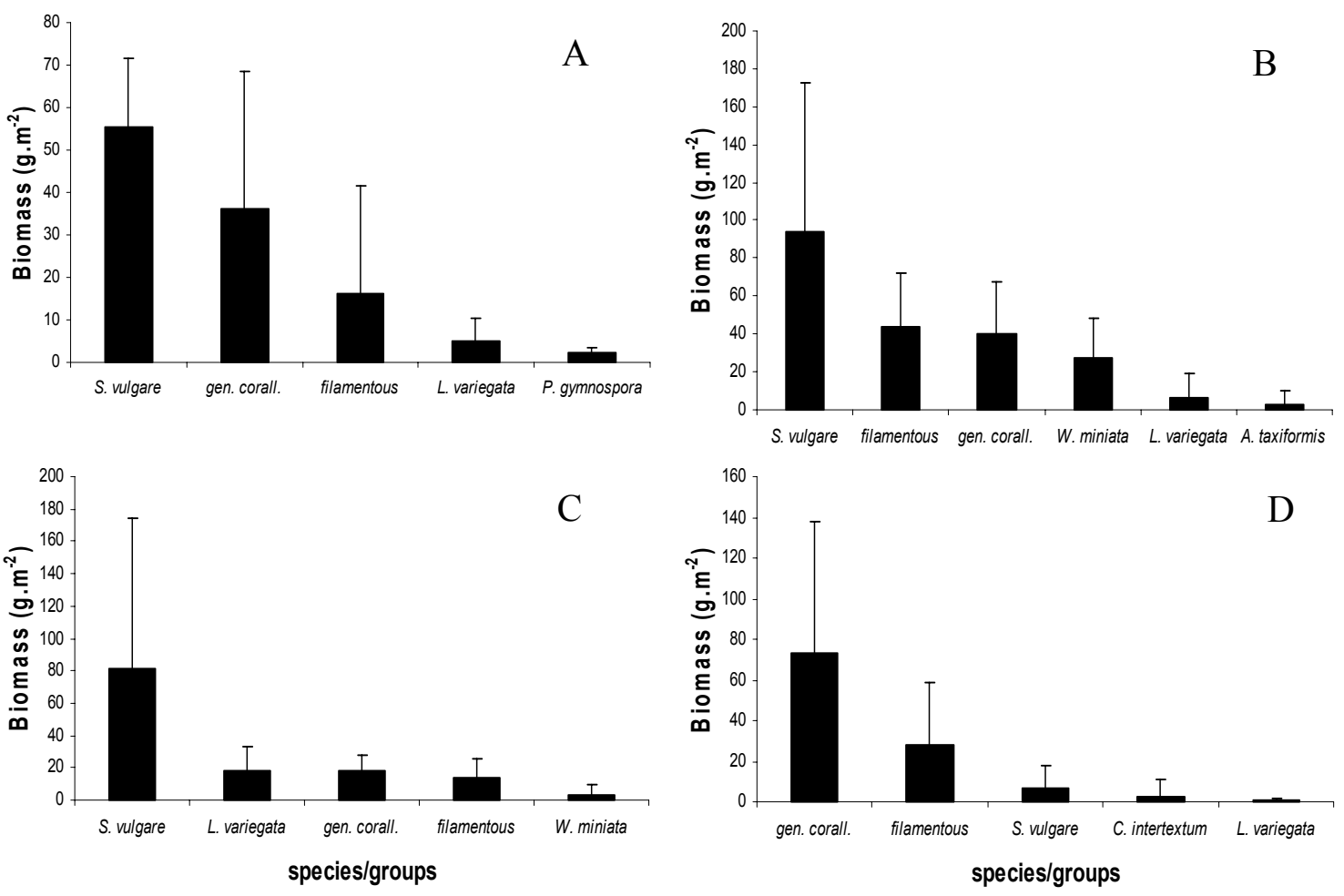

Fig. 4. Mean dry biomass (and standard deviation) of the main seaweed species and groups. A = January $20 \mathrm{~m}, \mathrm{~B}=\mathrm{January} 10$ $\mathrm{m} ; \mathrm{C}=$ October $20 \mathrm{~m}$; D = October $10 \mathrm{~m}$.

\section{Discussion}

The number of taxa (129) found in Laje de Santos corresponded to $45 \%$ of the seaweed flora of São Paulo State (277 taxa, Horta et al., 2001). This percentage, in addition to the 9 new records cited in this work, indicates that Laje de Santos Marine State Park, even considering its limited area, presents a high species richness. These results reinforce the necessity for the maintenance of the status of this conservation unity despite being relatively close to the largest urban center of the South America, the São Paulo metropolis. The results also stress the need to protect a representative portion of the biodiversity of the State and of the respective biogeographic province. It is important to mention that this study just considered the subtidal flora and that intertidal community studies must enhance the biological representative of this Conservation Unity.

Although the seaweed flora of Brazil is relatively well known, the number of species should be increased by 20 or $30 \%$, and one way to find new records is to study the unexplored subtidal zone (Oliveira, 2002). In this work, it was verified that about $8 \%$ of the species of Laje de Santos were new records, confirming the assumption of Oliveira (2002) that the subtidal zone is one of the main potential sources to find new records of seaweed species along the Brazilian coast.

When the two sampled seasons are compared in relation to floristic composition, the higher species richness was observed in the summer period at the $20 \mathrm{~m}$ depth. This result was expected as in the summer-fall period the frequency of typical storm disturbance conditions of the southeastern Brazilian coast is lower than that in the winter-spring period and it can be related to high species richness or diversity in the Brazilian continental shelf observed in the summer period (Soares-Gomes \& Pires-Vanin, 2003).

From the quantitative analysis it was verified that the majority of species (more than $90 \%$ ) are included in the two quantified groups, the filamentous group and geniculate coralline group. In fact, these groups form dense mats of small erect (up to $10 \mathrm{~mm}$ ) entangled filamentous, sheet-like and geniculate coralline macroalgae that have been considered as an ecological complex known as turf algae (Littler \& Littler, 1980; Steneck \& Dethier, 1994). A satisfactory definition of turf is that by Hay 
(1981): masses of tightly packed upright branches forming a stiff matrix more than $0.5 \mathrm{~cm}$ thick. Turfs may catch and hold significant quantities of sand, and the geniculate coralline algae act as "anchor" taxa persisting through the year and become re-established on exposed surfaces within several months (Stewart, 1983). The abundance of the turf-forming algae, specifically the geniculate coralline group, has been associated with the presence of Sargassum beds in rocky shores of Brazilian southeastern coastal region (Szechy \& Paula, 2000). The inter-specific competition between the geniculate coralline group and Sargassum has been indicated as the main mechanism to structure benthic communities in shallow subtidal zone of a rocky shore at Búzios, Rio de Janeiro (Oigman-Pszczol et al., 2004). Our results reinforce the importance of the turf form groups and Sargassum population to the structure of benthic communities in subtidal rocky shores. At Laje de Santos, mean Sargassum populations dry biomass was $59 \pm 38$ g. $\mathrm{m}^{-2}$, lower than that observed by Szechy \& Paula (2000) for populations of Sargassum exposed to wave-action sites in intertidal and upper region of the subtidal zone (mean dry biomass of $103 \pm 60$ g.m $\mathrm{m}^{-2}$ ). The individuals of $S$. vulgare sampled at Laje de Santos present short length (up to $15 \mathrm{~cm}$ long), absence of secondary axes and reduced number of leaves. The characteristic of $S$. vulgare populations and the abundance of turf-forming algae group in Laje de Santos indicate that benthic communities between $10-20 \mathrm{~m}$ depths were adapted to hydrodynamic conditions of strong water movements found in openocean areas of southeastern Brazilian coast.

In conclusion, from the analyzes of the subtidal marine benthic algal flora, the Marine State Park of Laje de Santos is to be considered as a site of elevated species richness. Its floristic composition is related to a benthic community structure dominated by a turf-forming group and populations of Sargassum vulgare.

\section{REFERENCES}

Chapin III, F. S.; Walter, B. H.; Hobbs, R. J.; Hooper, D. U.; Lawton, J. H.; Sala, O. E. \& Tilman, D. 1997. Biotic control over the functioning of ecosystems. Science, 277: 500-504.

Dirzo, R. \& Raven, P. H. 2003. Global state of diversity and loss. Annu. Rev. Env. Resour., 28:137-167.

Eston, V. R.; Migotto, A. E.; Oliveira Filho, E. C.; Rodrigues S. A. \& Freitas, C. 1986. Vertical distribution of benthic marine organisms on rocky coasts of the Fernando de Noronha Archipelago (Brazil). Bolm Inst. ocenaogr., S Paulo, 34:37-53
Hay, M. E. 1981. The functional morphology of turf-forming seaweeds: Persistence in stressful marine habitats. Ecology, 62:739-50.

Horta, P. A.; Amâncio, E.; Coimbra, C. S. \& Oliveira, E. C. 2001. Considerações sobre a distribuição e origem da flora de macroalgas brasileiras. Hoehnea 28:243-265.

Horta, P. A. \& Oliveira, E. C. 2002. Algamare-BR, Algas marinhas bênticas do Brasil. http://www.ib.usp.br/algamare-br/.

Littler, M. M. \& Littler, D. S. 1980. The evolution of thallus form and survival strategies in benthic marine macroalgae: Field and laboratory tests of a functional form model. Am. Nat. 116:25-44.

Neves, T. 1997. Dossiê de Gerenciamento do Parque Estadual Marinho da Laje de Santos, São Paulo: Instituto Florestal, Secretaria do Meio Ambiente. 2 v. 425 p.

Oliveira, E. C. de. 2002. Macroalgas marinhas da costa brasileira - estado do conhecimento, usos e conservação biológica. In: Araújo, E. L. et al., eds. Biodiversidade, conservação e uso sustentável da flora do Brasil. Recife: Sociedade Botânica do Brasil \& UFRPE. p:122-127.

Oigman-Pszczol, S. S.; Figueiredo M. \& Creed, J.C. (2004). Distribution of Benthic Communities on the Tropical Rocky Subtidal of Armação dos Búzios, Southeastern Brazil. Marine Ecology 25: 173-190.

Soares-Gomes, A. \& Pires-Vanin, A. M. 2003. Padrões de abundância, riqueza e diversidade de moluscos bivalves na plataforma continental ao largo de Ubatuba, São Paulo, Brasil: uma comparação metodológica. Rev. Bras. Zool., .20:717-725.

Steneck, R. S. \& Dethier, M. N. 1994. A functional group approach to the structure of algal - dominated communities. Oikos 69:476-498.

Stewart, J. G. 1983. Fluctuations in the quantity of sediments trapped among algal thalli on intertidal rock platforms in southern California. J. expl mar. Biol. Ecol., 73: 205-11.

Szechy, M. T. \& Paula, E. J. 2000. Padrões estruturais quantitativos de bancos de Sargassum (Phaeophyta, Fucales) do litoral dos estados do Rio de Janeiro e São Paulo, Brasil. Revta brasil. Bot., 23:121-132.

Wynne, M. J. 2005. A checklist of benthic marine algae of tropical and subtropical western Atlantic: second revision. Nova Hedwigia, 129:1-152.

Sources of Unpublised Material

Horta, P. A. 2000. Macroalgas do infralitoral do sul e sudeste do Brasil: taxonomia e biogeografia. Universidade de São Paulo. PhD Thesis. São Paulo, University of São Paulo. 301 pp. 